\title{
Celebrating 100 Years of Forest Management in British Columbia
}

The year 2012 marks the $100^{\text {th }}$

Anniversary of the British Columbia Forest Service (BCFS). The Forest Branch, which later became the BCFS, was established within the Department of Lands in 1912 to protect and manage the vast and diverse forests of the province. H.R. MacMillan of MacMillan Bloedel fame was the first Chief Forester from 1912-1915. The goals and objectives of the Service have been varied and diverse over the course of its history but all were designed to safeguard, promote and sustain the many facets of forest management throughout the province. Since its creation, the Forest Service has faced many challenges but has also accomplished many things. The overall goal, however, remains: to protect the public's interest and provide world-class leadership in the use of BC's forest and rangelands.

The forest resources of the province have been used for centuries, beginning with numerous Aboriginal groups, then European explorers and, with the birth of Canada, by Canadians. The first recorded use by Europeans was in 1778 by Captain James Cook. The gold rush of 1858 played an important role in the development of the interior of the province and increased the demand for lumber. Finally, by the latter half of the 1800 s, BC's logging operations and mills were well established.

The origins of the Forest Service can be traced back to the Royal Commission of Inquiry on Timber and Forestry of July 1909, which made 21 recommendations on forest management. The first Forest Act was drafted to implement those recommendations. Unfortunately, the First World War had a negative impact on the Service, as it did on many other "non-essential" aspects of the government. Not only did the government have to move funding elsewhere to pay for the war effort causing a significant decrease in research, but also the workforce was severely depleted due to enlistments. However, one positive outcome was the improvement in technology that could be used in all aspects of forest management. For example, there was an increased use of aircraft during the war that resulted in improved fire detection and suppression efforts post-WW1. There was also a massive effort to reforest part of Europe, and therefore new tree planting and cone collection techniques were developed and used in British Columbia. BC provided a core of knowledgeable workers and was a significant seed source during those reforestation efforts.

As with many forest services in the country, research into better ways to manage and harvest the forest are important parts of the job, and the BCFS was no different. In 1921, the first research program was the responsibility of James Alexander, who focused on timber utilization, slash disposal, natural regeneration, growth and yield, and fire protection. In 1923 it was recommended that an enlarged research program be established within the BCFS and by 1927 the Research Division had been created with a staff of seven and annual expenditures of \$34 000 .

At the end of the Second World War the Forest Service reported to its own Deputy Minister and was housed within the Department of Lands,

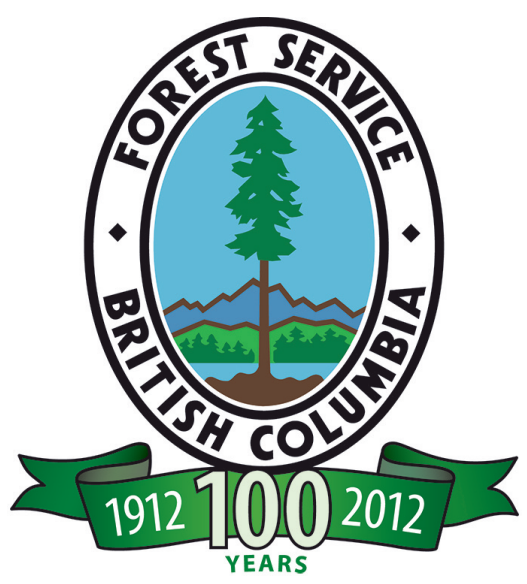

Forests and Water Resources. The year 1958 proved to be challenging as it was the worst fire season in the history of the province. Over 4000 fires, caused by railways, lightning and the public consumed more than 835000 hectares, mostly in the Prince George Forest District.

By the 1970s, the Research Division had expanded and expenditures and staff levels doubled. The approach to research also shifted during this time with more emphasis placed on

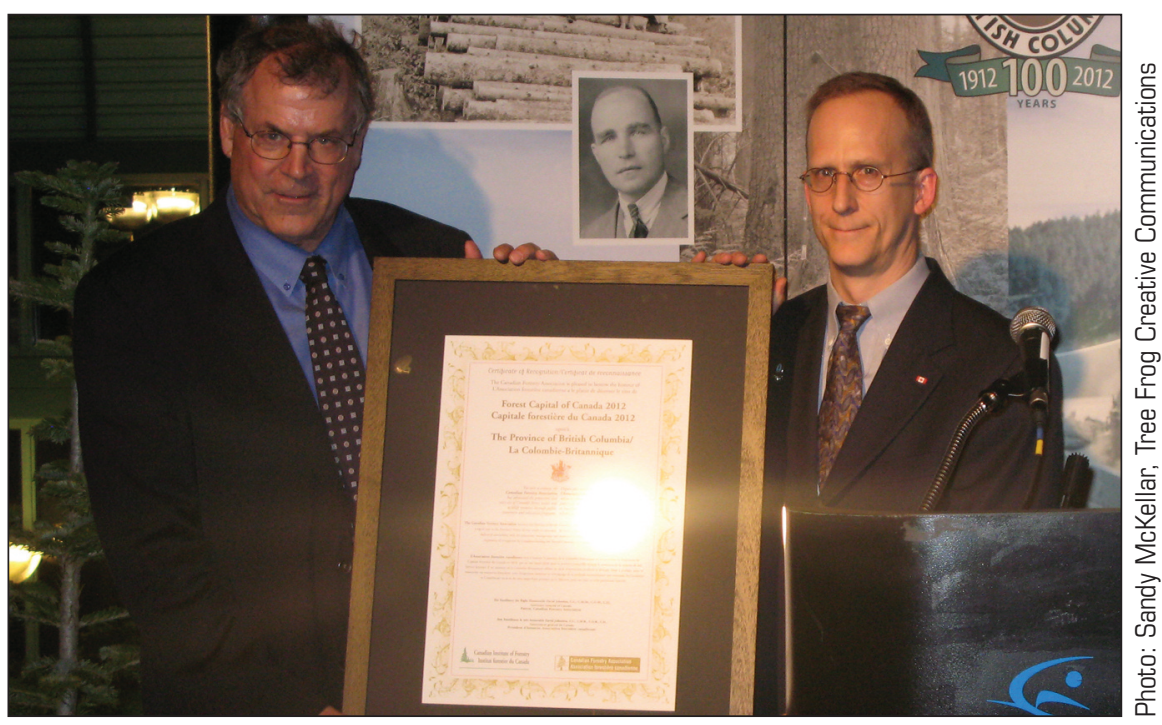

BC Minister Steve Thomson (left) receives the certificate of "Forest Capital of Canada" on behalf of the provincial forest service from CIF/IFC President Mark Kube, representing the CIF/IFC and the Canadian Forestry Association. 
ecological classification and integrated resource management. A Forest Research Board, made up of provincial, federal and industry representatives, was created in 1971 to prioritize research needs. The Forest Service was placed under the Ministry of Forests in 1975.

Beginning in the late 1980s, the Ministry of Forests went through several stages of re-structuring, and financial restraints were a major concern. Some of the issues facing the Ministry included timber supply, land use, forest management practices, economic efficiencies, and First Nations. Many of the issues still face the Ministry today, as it continues to forge into the $21^{\text {st }}$ Century and manage the forests of British Columbia.

Today, the BC Forest Service no longer exists under that name, but has been worked into the Ministry of Forests, Lands and Natural Resource
Operations (as of March, 2011) and is responsible for 59 million hectares of Crown land, covering two-thirds of the province. It is the steward of the timber, range and recreation resources of all of that land, which is managed for many uses including recreation, forage, timber, and wilderness. It cooperates with other agencies to manage water, fish, wildlife, tourism, heritage, energy and minerals. The forests of British Columbia are some of the most beautiful in the world and the BC Forest Service has done an excellent job over the last 100 years to ensure that the forests will be there for future generations to enjoy.

The BC Forest Service Centenary Society was created in 2008 to help coordinate centenary projects on behalf of the Ministry. The goals of the Society are to capture and document the rich history of the Service so that knowledge may be shared with current and future employees, students and the public. The
Centenary Society has many projects on the go to mark the $100^{\text {th }}$ anniversary, including a historical book, DVD, interactive Web site, special events, ceremonies, oral histories, and theme papers. The Centenary Society has also created a wonderful Web site that not only shares information about the events related to the $100^{\text {th }}$ anniversary celebrations, but is also a forum for people to share their stories and memories of the BC Forest Service. Visit www.bcfs100.ca to learn more about the celebrations, share stories and browse through the history of the British Columbia Forest Service. Congratulations to the BCFS and the Centenary Society. Enjoy a year of wonderful celebrations!

Laura Pickering CIF/IFC Historian/Archivist

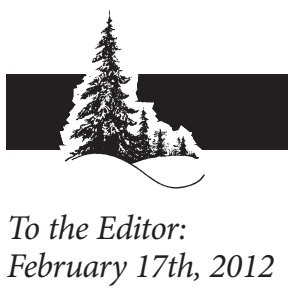

Slave Lake Fire Another Incident in a Long Line of Wakeup Calls for Alberta [and Canada)

attended the technical session "Living and Working in the Shadow of Wildfire" sponsored by the Rocky Mountain Section of the Canadian Institute of Forestry and Alberta Sustainable Resource Development held in Edmonton on November 2nd. I commend the organizers for a job well done. I am, however, deeply concerned about how the general public and we the forestry profession in Alberta perceive the wildfire that tragically impacted the Town of Slave Lake on May 15, 2011 and what we will do next. This was not a one-of-akind "finger of God" type of an incident.

In the immediate aftermath of the Slave Lake Fire, I received a number of calls from the media. A common question was "How could this have happened?" I pointed out that the conditions conducive to major, wind-driven fire runs occur virtually every summer. All that is needed is for an ignition to occur. And in the case of Slave Lake

\section{LETTERS $*$ LETTRES}

there was a vulnerable community immediately downwind. There are unfortunately lots of "Slave Lakes" out there just waiting to happen. The recent grass fires in southern Alberta near the end of November immediately come to mind. A similar set of circumstances occurred near Granum and Hinton in December 1997 (i.e., no snow cover and ignition sources coupled with exceptionally strong winds). Thankfully, no one was killed or seriously injured as a direct result of these fires-however, the next time this happens there might be an entirely different outcome altogether.

During one of the question and answer periods near the end of the November 2nd technical session, I mentioned that the Slave Lake Fire was just another example of a wakeup call in a long line of significant wildfire events beginning in 1995 in northern Alberta followed by the 1998 Virginia Hills, 2001 Chisholm, 2002 House River and 2003 Lost Creek wildfires, just to name a few. Fortunately, there were no injuries or deaths associated with these fires as well. Again, good fortune (i.e., lucky) or good planning? Normally you don't get many second chances when it comes to wildfires. Perhaps we are somewhat like cats but I humbly submit to you that we are not going to reach nine lives in most communities. Slave Lake is a testament to that.

Incidents like the Slave Lake Fire are not new, although many Albertans and probably most Canadians might not think so. In October 2010 I wrote a paper entitled "Lest We Forget": Canada's major wildland fire disasters of the past, 1825-1938 that recounts nine of the most devastating ones. Copies of this paper have been posted on a number of Web sites, including Partners in Protection (http://www.partnersinprotection.ab.ca/). In the paper I suggest that even in spite of the scientific and technological advances in controlling wildfires that have occurred over the years we are still at the mercy of good old Mother Nature. This is not to say that fire suppression is ineffective but fire management and forest management need to work even more closely together in the future in order to aid fire containment efforts. While the fuel type mosaic has indeed changed over time it is still capable of producing conflagrations and critical fire weather patterns 